\title{
Pastoralni i odgojno-katehetski naglasci sedmog i osmog poglavlja posinodalne pobudnice Amoris laetitia
}

\author{
Jadranka Garmaz*, Antun Volenik**
}

\begin{abstract}
Sažetak
Članak obrađuje pastoralne $i$ katehetske naglaske sedmog $i$ osmog poglavlja posinodalne apostolske pobudnice pape Franje Amoris laetitia — Radost ljubavi, koja nose naslov „Pojačati odgoj djece“ te „Pratiti, razlučivati i integrirati slabosti“. Ta dva poglavlja komprimiraju katehetsku i pastoralnu specifičnost pobudnice $i$ vrlo su izazovna jer obrađuju pitanje odgoja u obitelji, moralnog $i$ vjerskog odgoja te aktualiziraju neka zaboravljena pastoralna usmjerenja. Naime, do sada ni jedan od službenih dokumenta opće Crkve ne posvećuje toliko brojeva konkretnomu problemu (vjerskog) odgoja djece u obitelji, kao što je to vidljivo u sedmom poglavlju. Osmo poglavlje, u kontekstu izvanredne svete godine Božjeg milosrda, povezano je s promjenom mentaliteta koji pobudnica nudi, i to u smislu prezentiranja Crkve kao očeve kuće nasuprot slici Crkve kao carinarnice.

Ključne riječi: Amoris laetitia, odgoj u obitelji, moralni odgoj, odgoj vjere, razlučivanje, izvanredna Sveta godina Božjeg milosrđa
\end{abstract}

\section{Uvod}

Malo je koji dokument crkvenog učiteljstva zadnjih desetljeća izazvao toliku pažnju, ne samo teološke javnosti, kao posinodalna pobudnica Amoris laetitia o ljubavi u obitelji. Bazirana na zaključcima i prijedlozima dviju biskupskih sinoda iz 2014. i 2015. godine, tekst se pobudnice referira se na enciklike papa Ivana Pavla II. i Benedikta XVI., kao i mnogim katehezama i drugima dokumentima izrečenim od samog pape Franje. Tu su i druga dijela učiteljstva, različitih biskupskih konferencija (Kenije, Australije, Argentine), ali i osoba koje se ne susreću tako često u papinskim dokumentima te vrste, kao što su Martin Luther King ili Erich

* Izv. prof. dr. sc Jadranka Garmaz, Katolički bogoslovni fakultet Sveučilišta u Splitu. Adresa: Zrinsko-frankopanska 19, 21000 Split, Hrvatska. E-pošta: j.garmaz @kbf-st.hr

** Dr. sc. Antun Volenik, Sveučilište u Zagrebu — Fakultet za filozofiju i religijske znanosti u Zagrebu. Adresa: Jordanovac 110, 10000 Zagreb. E-pošta: voleniksj@gmail.com 
Fromm. Zanimljivo je uočiti i citat koji se referira na film Babettina gozba, ${ }^{1}$ tako dragog Papi, koji upravo kroz prizmu jedne pomalo disfunkcionalne obitelji progovara o ljepoti gozbe koja spaja i pomiruje i na koju su svi dobrodošli.

Zaustavimo se na uvodu, koji donosi rečenicu citiranu od mnogih ozbiljnih tumača i komentatora u trenutku kada je tekst objavljen: »Podsjećajući da je vrijeme važnije od prostora, želimo potvrditi da ne treba sva doktrinarna, moralna ili pastoralna pitanja rješavati intervencijom učiteljstva« te, iako je Crkvi potrebno jedinstvo učenja i prakse, »to ne isključuje različite načine tumačenja nekih vidova učenja ili nekih posljedica koje iz toga proizlaze« (AL 3), uzimajući $\mathrm{u}$ obzir kulture, tradicije i izazove u pojedinim zemljama.

Takva uputa i upozorenje predstavlja svojevrsnu novost: S jedne stane otvara pastoralno-katehetske obzore mjesnih crkvi, a s druge stane u toj istoj praksi može utjecati dezorijentaciju i nesnalaženje, što potvrđuju mnoge reakcije kardinala i biskupa. Iako na tom mjestu staro katehetsko načelo inkulturacije biva uzdignuto kao jedno od vodećih načela evangelizacije, ne treba zaboraviti da »kultura u koju smo danas uronjeni više nije mjesto ozbiljenja kršćanskog iskustva ljudske egzistencije i u konačnici mjesto očitovanja autentične kršćanske poruke« (Matulić, 2016, 79). Nešto od toga vidljivo je u drugom poglavlju pobudnice, koja nosi naziv Stvarnost i izazovi za obitelj. S jedne strane govori se o suvremenoj kulturi koja udaljuje slobodu i pravednost od istine, vrijednosti i načela te, s druge strane, o „kulturi provizornoga“. Unatoč tomu, Papa programatski načelno upućuje na izlazak iz zamke dualnosti svijeta i kršćanstva te u skladu s Gaudium et spes opominje kako kršćanski prijedlog ne treba biti samo »retoričko osuđivanje aktualnih zala«, što bi značilo upasti u zamku »sjetnih žalopojki« koje su daleko od »misijske kreativnosti« (AL 57).

Takav početak pobudnice jasno izražava katehetsku i pastoralnu usmjerenost Crkve, koja izlazi na periferije (EG 21) i pokazuje da cijela pobudnica ozbiljno uzima u obzir egzistencijalnu situaciju živog subjekta, pokušavajući pokazati da su i »iskustva sekulariziranog čovjeka teološki relevantna tj. da je ne samo moguć nego radi čovjekova cjelovitog dobra i nužan odnos sa živim i osobnim Bogom, koji ne uskraćuje svoju blizinu i komunikaciju s ljudima sekularizirane svijesti i savjesti« (Matulić, 2016, 85). Pobudnica polazi od analize postojeće situacije, kritičke prosudbe te situacije i već od prvih brojeva nastoji biti načelno smjerodavna i kontekstualna. To se načelo jasno odražava kako u jeziku, tako i u sadržaju, pa i u rasporedu devet poglavlja tog dokumenta, čija ćemo dva pretposljednja poglavlja (7. i 8.) u ovom radu komentirati, obrazložiti i istražiti s nakanom kontekstualizacije problematike kojom se bave. Upravo ta dva poglavlja usmjerena su na crkveno djelovanje (praxis) i to pod pedagoškim (odgoj), pastoralnim (praćenje) i duhovnim (molitva) vidom, kako dobro primjećuje Michael Sievernich baveći se tom pobudnicom (Sievernich, 2016, 358).

1 Film je naveden kao paradigma u pastoralno-katehetskom radu s obiteljima, koja nudi mogućnosti razumijevanja duboke poruke Evanđelja o Kristovoj gozbi i žrtvi, miru i izmirenju, grijehu i oprostu, ali razumijevanja i tog teksta u kontekstu godine milosrđa. Već na početku Pobudnice jasno se izražava poveznica prema suvremenoj kulturi, koju Papa želi izgraditi u svojem naviještanju, govorima i doktrinarnim tekstovima. 


\section{Odgoj vjere u obitelji u borbi sa slobodom i ograničenjima}

Odgoj vjere u obitelji ${ }^{2} \mathrm{u}$ današnjem kontekstu civilizacije spektakla i publiciteta, koja bježi od „teških pitanja“ i vođena je krajnjim individualizmom i konfuznim stavovima o vlastitoj slobodi bez odgovornosti, izgleda gotovo nemoguć. Današnja kultura življenja ističe ono što je poželjno, potrošivo i razonodljivo. Carpe diem mentalitet živi u obijesnoj sadašnjosti, kojega vrlo učinkovito podržava moćna medijska premreženost, ideali brzine i funkcionalnosti. Većini odraslih pak, a osobito djeci i mladima opčinjenima kompjutorskim igricama, nedostaje istinske orijentacije, ljudske topline i jednostavnosti (Koprek, 2005, 1-100). Pred takvim odgojnim izazovima obitelj se čini ostavljena na vjetrometini suvremenih strujanja bez bilo kakve potpore i pomoći. Ipak, dobrobit obitelji presudna je za budućnost svijeta i Crkve (AL 31), te Crkva želi pružiti »pomoć, poticaj i ohrabrenje obiteljima u njihovim svakodnevnim obvezama i izazovima « (AL 4) i pomoći im da svoju djecu odgoje da se puna nade suoče s budućnošću (Franjo, 2015a, 48-53).

Mnoga su istraživanja o odgoju (vjere) u obitelji. Jedno od posljednjih, autorica Garmaz i Gašpar, interdisciplinarne je prirode. ${ }^{3}$ Identifikacijom, izdvajanjem i usporedbom ključne terminologije izabranih vatikanskih dokumenata koji obrađuju temu obitelji i hrvatske teološke periodike u posljednjih dvadeset godina izdvojene su konkretne pojmovne relacije koje se vežu uz pojam obitelj s posebnim fokusom odgoja vjere u obitelji. Na temelju istraživanja višemilijunskog korpusa sa službenih stranica Vatikana autorice pokazuju da je obitelj na samom vrhu interesne ljestvice Crkve i da zajedno riječima život, Krist, vjera, human i odgoj $u$ vjeri sačinjava šestodijelnu jezgru i sadržajni fokus istraživanih izvora. Sadržajne i/ili vrijednosne relacije u kojima se nalazi riječ obitelj upućuju na mnogovrsnost odnosa, u kojima je obitelj od ključne važnosti. Prema navedenom istraživanju ključne terminologije, obitelj se nalazi u ovim najvažnijim relacijama: obitelj je temelj zajedničke koegzistencije i zajednica koja čuva društvo od društvene fragmentacije; obitelj je povlašteno mjesto za razvoj vrednota i ideala, to je mjesto za razvoj kreposti i milosrđa; obitelj je prva škola za razvoj identiteta i kompetencije zajedničkog življenja; obitelj je privilegirano mjesto za predaju vjere, ljudskog i religioznog naslijeđa, temeljna stanica društva i Crkve; obitelj je temeljna škola humanosti, domaća Crkva; obitelj je škola ljubavi i komunikacije.

Kao što vidimo, dosadašnji crkveni dokumenti su složni oko dragocjenosti i važnosti obitelji za opstanak čovječanstva i Crkve. Upravo na tom nasljeđu papa Franjo upustio se u višegodišnje istraživanje sadašnjeg stanja i budućnosti kršćanskih obitelji. Stoga pobudnica već na samom početku upućuje na dragocje-

2 Ne zaboravimo da se taj odgoj događa preko poslušnosti Božjoj Riječi. Djeci se treba posvjedočiti i predati zadaću: Neka ti Božja riječ bude u srcu i na ustima, jer ona ti je život i spasenje! Jedino temeljem poznavanja i poslušnosti Božjoj riječi možemo reći da odgajamo djecu u vjeri. U njoj su sadržani i moralni i vrijednosni i kreposni odgoj. Odgoj za praštanje i milosrđe su sadržani u Božjoj riječi i stoga je ona temelj odgoja za milosrđe (Kasper, 2015, 61).

3 Istraživanje je provedeno uz pomoć programa: WordSmith Tools, Version 5.0., Manual, Scott, M. 2010. i SDL MultiTerm Extract Manual, 2009. godine. Rezultati i teološka analiza dostupni su u članku: Garmaz i Gašpar, 2016. 
nost obitelji za Crkvu i dragocjenost Crkve za obiteljski prosperitet i opstanak. Budući da u ovom kratkom radu ne možemo temeljito prikazati sve te relacije između Crkve i obitelji, skicirat ćemo tek ulogu obitelji za odgoj zajedništva i rast u ljubavi, te dotaknuti privilegij obitelji za razvoj vjere i povlaštenost obitelji u razvoju kreposti i vrednota, jer su te teme središte same pobudnice.

\subsection{Prvenstvo obitelji u odgoju za vrednote}

Obitelj je put Crkve. Ivan Pavao II. u pismu obiteljima, ali i pape Benedikt XVI. i Franjo u svojim dokumentima potvrđuju prvenstvo obitelji u odgoju za vrednote (Kovačević, 2014) jer upravo one vrednote koje se usvajaju u obitelji, ostaju trajne za cijeli život. Jedna od istaknutih vrednota upravo je ljubav koja se živi u obitelji. Utoliko je obitelj i prva škola ljubavi i povjerenja, škola milosrđa i praštanja. Tu tezu potvrđuju i istraživanja ključnih riječi u spomenutim dokumentima, jer se obitelj pojavljuje na samom vrhu najfrekventnijih riječi u dokumentima, i to u konstitutivnom odnosu prema životu, Kristu, humanom, vjeri i odgoju vjere. Budući da se istraživani izvori i vatikanski i hrvatski preklapaju, možemo reći da je prisutan svojevrsni konsenzus među dokumentima i tvrdnji za konstitutivnost i nosivost obitelji kao osnovne stanice društva i Crkve. Ona je škola osnovne, temeljne ljudskosti, škola ljubavi i zajedništva.

Papa Franjo u svojim govorima i katehezama ističe da je pitanje o moralnom odgoju djece vrlo važno i zato sedmo poglavlje Amoris laetitia posvećuje toj problematici. ${ }^{4} \mathrm{Na}$ početku polazi od općenite tvrdnje da roditelji uvijek utječu na moralni razvoj djeteta — bilo na dobro, bilo na loše. Zbog toga je najbolje ako oni svoju neizbježnu zadaću prihvate i dobro je izvrše (AL 259). Nakon toga Papa vrlo konkretno, govorom koji do sada nije bio prisutan u dokumentima crkvenog učiteljstva, otvara pitanje odgojnih izazova obitelji te nudi konkretne metode, sadržaje i načela tog odgoja. Katehetski i pastoralni djelatnici nisu mogli zamisliti konkretniji govor i smjerokaz za rad na svojem području. Stoga se taj tekst može gotovo doslovce ponuditi za rad u obiteljskim skupinama i roditeljskim katehezama. To poglavlje, uz četvrto i peto, potvrđuje prvenstvenu namjenu pobudnice: onima na terenu, katehetskim i pastoralnim djelatnicima, a još više roditeljima i supružnicima. Taj zaokret u komunikaciji, sadržaju i cilju pobudnice također je katehetska i pastoralna novost Papina djelovanja, koja je u tom slučaju sama po sebi razumljiva jer je riječ o obiteljima i njihovom poslanju.

Zato u dva broja Papa postavlja pitanje o novim metodama i sredstvima zaštite i vođenja djece. Upozorava na činjenicu da roditelji trebaju promisliti o tome što svojoj djeci žele posredovati. Zato je »neizostavno upitati se tko se brine o tome da se djeci stvori radost i zabava u slobodno vrijeme, tko im preko ekrana ulazi u stan, kojem su vodstvu djeca prepuštena u slobodno vrijeme« (AL 260). Tako započeta misao o odgojnoj problematici jasno daje do znanja da je papa svjestan suvremenih odgojnih izazova i da mu svakodnevica današnjih obitelji

4 To se poglavlje dijeli na sljedeće teme, koje su ujedno i podnaslovi: Gdje se nalaze djeca?; Etički odgoj djece; Poticajna vrijednost kazne; Strpljivi realizam; Obiteljski život kao odgojno okružje; Da spolnomu odgoju, Prenošenje vjere. 
nije strana. Početak nedvosmisleno poziva roditelje na budnost i na svijest vlastite odgovornosti. Roditelje se poziva da promisle: Što svojoj djeci žele prenijeti kao vrednotu i stav? Koja je najvažnija poruka koju im žele prenijeti, što im u stvari žele reći? To je pitanje ključno i poziva roditelje na oprez da ne zaborave što im je u životu najvažnije, najdragocjenije i što svojoj djeci žele utisnuti u srce.

Oprez prema medijima i ekranima te prema zabavi koju pružaju djeci svojevrstan je nastavak odgojne misli Ivana Pavla II., koji u apostolskoj pobudnici Crkva $u$ Aziji, ističe da negativni aspekti industrijâ medija i zabave na poseban način ugrožavaju svetost braka i stabilnost obitelji. Tu misao papa Franjo preuzima i u apostolskoj pobudnici Evangelii Gaudium (EG 66-67).

Papa nadalje svjestan situacije nastavlja o brižnosti roditelja i zabrinutosti roditelja za djecu i tu misao izoštrava s jasnom upozorenjem: »Pretjerana briga ne odgaja i roditelji ne mogu imati pod kontrolom sve situacije u koje dijete može upasti« (AL 260). Stoga je ta opomena dobrodošla svima koji pretjerano brinu i kontroliraju svoje dijete te on tu kontrolu zamjenjuje konkretnom smjernicom za izlazak iz te situacije. Gotovo programatski, Papa se opet osvrće na svoje poznato načelo ${ }^{5}$ da $»$ vrijeme je važnije od prostora! To znači da roditelji umjesto kontroliranja prostora u kojem se dijete kreće trebaju prionuti za posao odgoja koji će pripraviti dijete na izazove koji mu predstoje « (AL 260 ili EG 260). Time Papa želi naglasiti kako je potrebno poticati rast slobode i sposobnosti cjelovitog razvoja djeteta ta ga pratiti do njegove prave samostalnosti.

Ako te misli usporedimo s prethodnim papom, možemo vrlo lako uočiti da je i papa Benedikt XVI. kao veliki kateheta i učitelj vjere naglašavao upravo postupnost rasta u slobodi i istini: »Ne trebamo se plašiti skromnosti malih koraka i pouzdavanja u kvasac koji se miješa sa tijestom i čini da ono polako raste (usp. Mt 13, 33)« (Benedikt XVI., 2012). On je također snažno naglašavao katehetsku zadaću obitelji, tvrdeći da su roditelji pozvani obnoviti svoju ulogu prvih navjestitelja vjere (LG 11, AG 11) i prihvatiti tu odgojnu odgovornost prvih kateheta i učitelja u vjeri svoje djece i to odgajanjem savjesti svoje djece i otvaranju iste prema Božjoj ljubavi kao temelju njihova života. »Važno je pomoći svim članovima obitelji da shvate da vjera nije neki teret, nego izvor duboke radosti, da vjerovati znači zamijetiti Božje djelovanje, prepoznati prisutnost dobra, koje ne diže buku; i da vjera pruža dragocjene putokaze za življenje vlastite egzistencije« (Benedikt XVI., 2012).

Vrlo sličnu tendenciju buđenja katehetske odgovornosti roditelja preuzima i papa Franjo već na generalnoj audijenciji 20. svibnja 2015., kada je postavio pitanje roditeljima: »Pokušavamo li razumjeti gdje se djeca zbilja nalaze na svom putu? Znamo li gdje je stvarno njihova duša? I prije svega želimo li znati? « (AL 261).

Već u tih nekoliko brojeva uočava se naglasak na roditeljima kao prvim vjerovjesnicima i katehetama. Ta je kateheza roditelja unutar svoje obitelji usmjerena na etički odgoj djece kao i odgoj savjesti i otvaranje prema Božjoj ljubavi. Odgojna odgovornost roditelja naglašena je više puta i istaknuta je kao bezuvjetno načelo odgoja za vrednote. Tako tradicionalni katehetski nauk po kojem odrasli preuzimaju brigu za katehezu ponovno izranja kao katehetska paradigma za naše

5 Kao pater provincijal Jorge Bergoglio SJ koristio je to načelo i ono je jedno od četiri pastoralnofilozofska načela u EG 217-237. 
vrijeme. S druge strane, tek se na kraju poglavlja upućuje na katehetsku pomoć roditeljima od strane kršćanskih zajednica. One moraju biti takve da pokazuju preobražavajuće djelovanje Božje milosti, čega je i papa Benedikt XVI. u svojoj katehezi od 28. studenog 2012. bio svjestan. Tu misao u toj pobudnici doduše ponavlja papa Franjo, ali je ne razrađuje. No, crkvena zajednica kao subjekt i mjesto kateheze mora postati mjesto naviještanja Krista, a ne sebična, zatvorena, ravnodušna zajednica, čega se i papa Benedikt XVI. u spomenutoj katehezi pribojava. Ta uloga crkvene zajednice u pastoralu i katehezi braka i obitelji u tom dokumentu ostaje na rubu te je u opasnosti da umjesto katehetskog središta sama postane „periferija“. 6

\subsection{Moralni odgoj je školovanje slobode}

O etičkom odgoju djece eksplicitno se u pet brojeva dotiču konkretne odgojne teme. Do sada ni jedan od službenih dokumenta opće Crkve ne posvećuje tako konkretno toliko brojeva problemu etičkog odgoja djece u obitelji. Papa smatra da roditelji, iako potrebni pomoći i oslonca u školi glede etičkog odgoja svoje djece, taj isti odgoj ne smiju ispustiti iz svojih ruku jer se »emocionalni i etički razvoj čovjeka temelji na iskustvu vjerodostojnosti vlastitih roditelja« (AL 263). Radi toga je potrebno da roditelji preuzmu na sebe odgovornost u području odgoja te na temelju vlastitog primjera bude u djeci povjerenje i poštovanje puno ljubavi. ${ }^{7}$

Odgojna zadaća roditelja vrlo je konkretna i sastoji se u davanju živog svjedočanstva vjere (HBK, 2002, 27). Prema Amoris laetitia za etički odgoj odlučujući je odgoj volje i razvoj dobrih navika, kao i unutarnje nastojanje u dobru. Moralni odgoj se mora uvijek odvijati s aktivnim metodama i odgojnim dijalogom koji pretpostavlja osjetljivost djece i njihov vlastiti način govora. Osim toga, odgoj se mora odvijati induktivnim putem, da se djetetu omogući da otkrije značenja određenih vrijednosti, temelja i pravila umjesto da mu ih se prisilno nametnu kao neodbacive istine (AL 264). To je pravi izazov za današnje obitelji, koje moraju pronaći načina da njeguju kulturu dijaloga i pokreću procese rasta u slobodi svoje djece. ${ }^{8}$

6 Dajući u javnu raspravu radni tekst dokumenta Da vaša radost bude potpuna (HBK, 2016a), hrvatski su biskupi ukazali na važnost i neizostavnost župne kateheze u katehetskim procesima, osobito onim obiteljskim, iako tek nakon 16 godina od Plana i programa župne kateheze. Ipak, nadamo se, ne u zadnji čas.

7 Ako usporedimo s već citiranim govorom pape Benedikta XVI., uočavamo sadržajni katehetski kontinuitet, ali je razlika u načinu govora. Dok je kod pape Benedikta XVI. taj govor sadržajno jezgrovit, upućen onima koji su dobri poznavatelji vjere, papa Franjo njeguje jednostavniji govor, razumljiv i onima koji ne poznaju vjeru ili su se od nje udaljili: »Govoriti o Bogu, dakle, znači svojom riječju i životom pomoći drugima da shvate da Bog nije takmac našega života, već je njegov pravi jamac, jamac veličine osobe. Tako se ponovno vraćamo na početak: govoriti o Bogu znači riječju i životom komunicirati, snažno i jednostavno, ono što je bitno, a to je Bog Isusa Krista, onaj Bog koji nam je pokazao tako veliku ljubav da se utjelovio, umro i uskrsnuo za nas; onaj Bog koji traži da ga slijedimo i da dopustimo da nas preobrazi njegova neizmjerna ljubav kako bismo obnovili svoj život i svoje odnose; onaj Bog koji nam je darovao Crkvu, da bismo zajedno kročili ovim svijetom i, po Riječju i sakramentima, obnovili čitav ljudski grad, da može postati Božji grad« (Benedikt XVI., 2012).

8 U već spomenutoj katehezi papa Benedikt XVI. naglašava isto: »Na kraju, tu je i sposobnost slušanja i dijaloga: obitelj mora biti ambijent u kojem se uči živjeti zajedno, izgladiti sporove u 
No, za život u slobodi, za ispravno postupanje nije dovoljno poznavanje sadržaja i moralnih normi ili vrednota. Štoviše, u vremenu rasipničkog i pretjeranog konzumističkog razvoja (CV 35), iznimno je važno razvijati vrline i kreposti. U toj se točci slažu i prethodni pape te ističu nužnost odgoja za kreposti. Tako sv. Ivan Pavao II. upozorava kako je danas glavna prijetnja, s kojom smo svi suočeni, smanjenje ljudske dimenzije (MD 30), a papa Benedikt XVI. upozorava na podvojenost kršćanskog odgoja mladih kada kaže da se naglašava i odgaja emotivnost i ono što je specifično ljudsko, ali se ne odgaja za izbor vjere u Isusa Krista (Benedikt XVI., 2008). Bitna svrha odgoja je prema papi Benediktu XVI. formiranje osobe kako bi je se osposobilo da živi u punini i da dade vlastiti doprinos dobru zajednice. U neke od zadaća izvornog odgoja prema papi Benediktu XVI. spada da u odgoju treba darovati određeni dio samog sebe, da na brojna pitanja mladih treba nadovezati pitanje koje se odnosi na istinu, i to onu koja može biti vodič u životu, da je patnja dio istine našeg života jer sposobnost za ljubav odgovara sposobnosti za trpljenje, te da je najosjetljivija točka odgoja pronalaženje ravnoteže između slobode i stege.

Uspoređujući te tvrdnje o odgoju pape Benedikta XVI. s već spomenutima pape Franje iz sedmog poglavlja posinodalne apostolske pobudnice Amoris laetitia, uočavamo kontinuitet i svjedočimo preuzimanju glavnih odgojnih smjernica od pape Benedikta XVI. Na njegovoj tradiciji papa Franjo naglašava veliku važnost osobe odgajatelja. On poziva roditelje na svijest vlastite odgojne autentičnosti i na odgovorno preuzimanje zadaće odgoja svoje djece. U društvu delegiranja odgovornosti, obojici papa na srcu je zadaća da posvijeste roditeljima odgovornost i kompetenciju za odgoj vlastite djece, a osobita roditeljska ingerencija nalazi se u području njegovanja obostrane ljubavi, postojanog svjedočenja, pomaganja djeci da razlikuju dobro i zlo i u izgradnji trajnih životnih pravila. Na općoj audijenciji 20. svibnja 2015. papa Franjo potvrdio je taj poziv roditeljima govoreći: »Kucnuo je čas da se očevi i majke vrate iz svoga izgnanstva — jer su sami sebe prognali iz odgoja djece - i ponovno na sebe potpuno preuzmu svoju odgojnu ulogu. Nadam se da će Gospodin dati roditeljima tu milost: da ne prognaju same sebe iz odgoja djece. A to može učiniti samo ljubav, nježnost i strpljivost $«($ Franjo, 2015c).

U moralnom je odgoju neizostavno razvijati navike. ${ }^{9}$ »Iako je sama Riječ Božja izvor mudrosti, sama mudrost stječe se uz mučan napor «(Fuček, 2004, 26). Zato su pozitivne navike od ranog djetinjstva vrlo važne jer se na njima mogu dalje graditi unutarnje vrijednosti i zdravi odnosi. Jačanje volje i ponavljanje određenih stavova grade temeljni moralni stav, i bez svjesnog, slobodnog i voljnog ponavljanja određenih dobrih temeljnih stavova ne može se u odgoju stići do rečenog cilja. Atraktivnost i razlozi za usvajanje određenih vrijednosti neće postati krepošću bez

uzajamnom dijalogu, koji čine slušanje i riječ, jedni druge razumjeti i međusobno se ljubiti, da bi jedni drugima bili znak Božje milosrdne ljubavi« (Benedikt XVI., 2012).

9 Stari su govorili da čovjek prestaje biti čovjekom kad izgubi osjećaj za moralni red (Šimundža, 2000,137). O mudrosti starijih pisao je i Ivan Pavao II. (1999). Papa Franjo također izjavljuje na općoj audijenciji 4. ožujka 2015. da gdje nema poštovanja prema starijima, tamo nema budućnosti za mlade (Franjo, 2015b). 
prikladno motivirajućih djela. Nadalje, moralni je odgoj jedno školovanje slobode, koje gradi krepost, jača je i odgaja te tako izbjegava da čovjek postane rob onečovječujućih i nesocijalnih ponašanja. Ljudski bitak naime iziskuje da svaki u svjesnom i slobodnom izboru djeluje, što znači osobno, iznutra da bude vođen i pokrenut (Fuček, 2004, 266-267). Tu misao o školovanju slobode na temelju vjere i o angažmanu oko kreposnog življenja više puta ističe i veliki etičar, sv. Ivan Pavao II. U enciklici Veriatis splendor on je jasno rekao da »vjera posjeduje i moralan sadržaj: ona stvara i zahtijeva angažman koji je dosljedan životu, ona podupire i usavršuje prihvaćanje i obdržavanje Božjih zapovijedi« (VS 89).

Papa Franjo polazeći od te ideje, vrlo jednostavnim, mjestimice slikovitim jezikom, u pobudnici Amoris laetitia predstavlja pedagogiju koja počinje s jednom idejom, ide preko osjećaja i posreduje jednu sliku. Taj govor sličan je parabolama i stoga je razumljiv današnjemu čovjeku. To je možda najveća razlika pape Franje u odnosu na prethodnike — jezik kojim naviješta istinu vjere. Tu lakoću govora u slikama, primjerima, parabolama i usporedbama vidimo i u usporedbi vjere i hranjenja. Naime, u svim tim naputcima i prijedlozima Papa nikako ne želi nestrpljivo nametanje vjere, nego govori o „hranjenju“ na način prikazan u njegovu omiljenom filmu Babettina gozba. »Čak i savjeti o odgoju djece orijentirani su ka strpljivom „hranjenju“ omogućujući im tako da se osjete „vrijednima“ kako je prikazano u filmu « (Fares, 2016, 357).

To mišljenje dijeli i kardinal Schönborn, koji smatra da je papa Franjo pobudnicom htio približiti doktrinarni pogled na temu braka i obitelji te ponuditi pogled dobrog pastira koji ima razumijevanja i suosjećanja s ljudskim slabostima i greškama. Taj pogled na konkretno i osjetljivost za najslabije čini ključ Franjine pobudnice (Radio Vatikan, 2016a). Prema kardinalu, Franjina je slika obitelji bliska biblijskomu realizmu, a ne apstraktnomu idealu ili sekularnomu pogledu na obitelj. Biblija naime ne donosi sliku idealne obitelji, nego pokazuje da je i tu riječ o grešnicima koji se nalaze na putu obraćenja. Po tome je prema Schöenbornu Amoris laetitia smještena u dugu crkvenu tradiciju koja vuče korijenje od sv. Tome Akvinskog i sv. Ignacija Loyolskog: dalje od rigorizma k moralu koji uključuje cijelu osobu. Taj su put papi Franji utrli prethodnici sv. Ivan Pavao II. i papa Benedikt XVI.

\section{Osmo poglavlje — „vrući krumpir“ili pastoralni kairos}

Osmo poglavlje Amoris laetitia ne može se čitati bez konteksta izvanredne Svete godine milosrđa kao pozadine na kojoj je pobudnica nastala. Mnogi su tek po objavljivanju dokumenta pozornije pročitali Papine propovijedi i angleuse izrečene kroz dvije godine njegova dotadašnjeg pontifikata, koje zapravo obiluju referencama i pozivima na dublje otkrivanje Božjeg milosrđa. Navedimo tek jedan primjer. Papa Franjo, nakon povratka sa Svjetskog dana mladih održanog u Rio de Janeiru 2013., referirajući se na pitanje novinara G. G. Vechia, koji je primijetio da Papa puno govori o milosrđu te time povezao svoje pitanje može li se u tom kontekstu što učiniti glede pričesti ponovo vjenčanih, rekao je: 
Milosrđe je puno veće od slučaja koje spominjete. Mislim da će ovo biti vrijeme milosrđa. Ova promjena epohe, ali i mnogi problemi u Crkvi — kao što su loši primjeri nekih svećenika, pa problemi korupcije u Crkvi, pa čak i problem klerikalizma, da spomenem samo neke primjere - mnoge je ranilo, mnoge je ranilo. A Crkva je Majka: mora ići i brinuti se za ranjene i to s milosrđem. No, ako Gospodin neumorno oprašta, ni mi nemamo drugog izbora nego upravo to: prije svega liječiti ranjene. Mama je, Crkva, i mora ići dalje tim putem milosrđa. I to pronalaženjem milosrđa za sve. (...) To je milost. I vjerujem da je ovo kairos: ovo je vrijeme kairos milosrđa. Ali prvu intuiciju imao je svakako Ivan Pavao II., kada je sve počeo s Faustinom Kowalskom, Božanskim Milosrđem (...) imao je nešto, shvatio je da je to bila nužnost tog vremena (Franjo, 2013).

Postoji puno drugih tekstova koji potvrđuju tu tvrdnju o čestom spominjanju milosrđa i praštanja kao osobito drage teme, koju je papa razrađivao u svoje prve dvije godine pontifikata. ${ }^{10}$ Ipak, zapazimo jedan tako tipičan pastoralni izraz koji možemo vidjeti u gore citiranom tekstu »ovo je kairos« (istaknuti dio teksta). To se pokazalo i u buli proglašenja izvanrednog jubileja milosrđa Misericordiae Vultus (MV 15) kao i u navedenom dijelu pobudnice.

\subsection{U ozračju milosrda}

Ovim uvodom željeli smo ne samo oslikati povijesnu pozornicu, nego i kontekst onoga što, u pastoralnom smislu, obilježava osmo poglavlje Amoris laetitia. Kao primjere možemo izdvojiti izjave poput: »Put Crkve je ne osuditi nikoga zauvijek; izlijevati balzam Božjeg milosrđa na sve one koji to iskrena srca traže« (AL 296). To je još jasnije izrečeno u brojevima 309-310, u potpunosti prožetima citatima bule otvorenja izvanredne godine milosrđa Misericordie Vultus (AL 309-310). ${ }^{11}$

Iako je srce i centar pobudnice zapravo četvrto i peto poglavlje, te ostala dva koja su izravno upućena roditeljima i odgojiteljima, ono što ju je učinilo tako „vrućim krumpirom“ u mnogim teoloških raspravama upravo je njezino osmo poglavlje, osobito ono što se odnosi na neregularne situacije, te su ne samo brojevi, nego čak i fusnote izazvale cijelu lavinu komentara i naknadnih oprečnih tumačenja. ${ }^{12}$

Što se dakle nalazi u osmom poglavlju? Jedan od zaključaka koji možemo izvesti iz tog teksta mogao bi se definirati ovako: Da, brak je nerazrješiv, ali je još više nerazrješiv vez između Crkve i Božjeg naroda, kako je to definirao Drugi vatikanski sabor (LG 10). U tom naporu da prati, razlučuje i integrira upravo obitelji i parove koji proživljavaju lomove i doživljavaju slabosti to poglavlje nastoji otvoriti perspektive bez rigidnosti „carinarnice“, a to može plašiti i uznemiravati isto kao što uistinu može dovesti do preširokog tumačenja, pa i zloupotreba u tumačenju pozitivnih crkvenih normi i poklada učiteljstva. Zaustavimo se zato

10 Spomenimo samo neke: Angleus od 15. rujna 2013., 9. srpnja 2013., 7 rujna 214. te 15. veljače 2015.; propovjedi u Bazilici sv. Petra od 13. ožujka 2015.; Obraćanje zatvorenicima Poggioreale 21. ožujak 2015.; propovijed u Seulu 18. kolovoza 2014. Svi navedeni tekstovi dostupni su na URL: http://w2.vatican.va/content/francesco/it/homilies/2015.index.3.html (22.10.2016.)

11 Dokument se, naime, referira na MV devet puta, od čega direktnim citatima 6 puta.

12 Tu mislimo osobito na fusnote 331 i 336. Pojedine reakcije išle su od izraza zabrinutosti sve do otvorenog govora o heretičkim interpretacijama: Murdoch, 2016; Pismo katoličkih profesora filozofije i teologije, 2016; Catholic Herald, 2016. 
kratko na te tri riječi koje žele opisati „milosni“ zaokret u pastoralu neregularnih situacija: praćenje, razlučivanje i integracija ranjivosti.

\subsection{Praćenje, razlučivanje $i$ integracija ranjivosti}

Pastoralno ili katehetsko praćenje je izraz koji ne nalazimo često u teološkoj literaturi. ${ }^{13}$ Ono ima elemente onoga što se nekada nazivalo duhovno vodstvo, ali i onoga što se danas naziva pastoralno savjetovanje (counseling), na što pobudnica također poziva (AL 203-204). Pastoralno praćenje bitan je sastojak svake pastoralne strategije, osobito kad je riječ o rubnima ili onima koji se tako osjećaju, jer u sebi nužno uključuje stvaranje odnosa, ponekad u dugoj i ne uvijek ugodnoj dinamici. Odnos takve vrste bitan je da bi se do takve osobe došlo na dubljoj razini. Ali pratnja samo zbog pratnje i nije pastoralna strategija u evangelizacijskom smislu. Naš cilj ne može biti samo pratiti — taj zajednički hod mora imati neki cilj. U konačnici on je usmjeren za vjerničko, često i emotivno-psihološko zrenje i odrastanje vjernika, što uključuje i poučavanje, vođenje i promjenu života ljudi kroz posvećenje u istini i sakramentima. Evanđeoski primjeri koji se najčešće navode jesu „prst“ Ivana Krstitelja i učenici na putu za Emaus. Ivan Krstitelj pokazuje na Isusa, ali ne donosi odluku umjesto svojih učenika, niti ih veže za sebe, nego tek prati za susret s njim. Isus, anoniman, sluša i pita hodajući s njima na „krivom“ putu ili smjeru (idu iz Jeruzalema). Tek kada dođu do cilja — prepoznavanja Isusa u euharistiji, oni se „okreću“, idu istim putem, ali u pravom smjeru. Iako je slušanje vrlo bitan dio praćenja, ono u nekom trenutku treba prerasti u aktivnu dinamiku, što nas uvodi u drugu stepenicu koju nam pobudnica daje, a to je razlučivanje.

\subsection{Razlučivanje}

Mnogi su primijetili da je razlučivanje onaj ignacijanski znak ${ }^{14}$ koji otkriva papu isusovca (Martin, 2016). Štoviše, već površni pogled na poglavlje koje obrađujemo otkriva kako je pojam razlučivanja zapravo središnja misao. Naime, od pet podnaslova središnja su tri (Razlučivanje u neregularnim situacijama; Olakotni čimbenici u pastoralnim razlučivanju; Norme i razlučivanje) usmjereni direktno na razlučivanje. ${ }^{15}$ Iako među samim isusovcima i osobama koji slijede ignacijansku duhovnost taj izraz spada na samu srž ove karizme, u širem vjerničkom pa i teološkom diskursu ni taj izraz nije previše poznat. Zato se može reći da su »neke prijeporne točke glede ovog važnog teksta Učiteljstva nastale upravo zbog nesposobnosti razumijevanja što bi bilo razlučivanje i kako ga živjeti« (Spadaro i Cameli, 2016, 3). ${ }^{16}$

13 O katehezi kao pratnji na putu vjere vidi u: Garmaz i Kraml, 2010.

14 Bilo bi pogrešno i teološki netočno tvrditi kako je sv. Ignacije „izmislio“ razlučivanje duhova. Izraz „razlučivanje duhova“ (diakriseis peneumatôn) nalazimo već kod sv. Pavla u poznatom tekstu o darovima Duha, nabrojan kao jedan od tih darova (1 Kor 12,10). Sličan izraz „provjeravajte duhove" (dokimazeta ta pneumata) nalazimo na početku četvrtog poglavlja Prve Ivanove poslanice u vrlo jasnom kontekstu razlučivanja onoga što potiče od Kristova nasuprot Antikristovu duhu.

15 Izraz se u cijeloj pobudnici koristi pedesetak puta.

16 Uz taj članak svakako treba spomenuti i Sievernichev članak, koji obrađuje upravo temu razlučivanja u kontekstu te pobudnice (Sievernich, 2016). Cijeli taj broj Theologische Quartalschrift posvećen je pobudnici Amoris laetita. 
Što zapravo Papa želi reći naglašavajući potrebu razlučivanja? O tome on govori odmah na početku pobudnice u kontekstu nedovoljnog povjerenja $\mathrm{u}$ mogućnost samih bračnih parova koji, ukoliko su otvoreni zahvatima milosti, mogu i trebaju rasti u razlučivanju koje počiva na njihovim problemima i izazovima:

Dugo smo mislili da smo jednostavnim isticanjem doktrinarnih, bioetičkih i moralnih pitanja, bez poticanja na otvaranje milosti, već pružili dovoljnu potporu obiteljima, učvrstili bračnu vezu i ispunili smislom njihov zajednički život. Nailazimo na teškoće u predstavljanju i braka više kao dinamičkog puta osobnog razvoja i ispunjenja, no kao teret koji treba podnositi cijeli život. Mučimo se također dati prostor savjesti vjernika, koji usred svojih ograničenosti vrlo često odgovaraju što je bolje moguće na evanđelje, te su sposobni ostvariti svoje vlastito razlučivanje u složenim situacijama. Pozvani smo odgajati savjesti, a ne težiti tome da ih zamijenimo (AL 37).

Ovdje je potrebno pobliže vidjeti što znači Papin izraz »formirati savjesti« kroz stvaranje prostora za osobno razlučivanje. Sažeto rečeno, misli se na razlučivanje koje osobi pomaže da se suoči sa stvarnošću polazeći iz svoje osobne situacije i zato može pomoći u takvoj vrsti pastorala. Takvo razlučivanje smjera ka dubljemu rastu osobe i može postavi pravi »ključ odraslog kršćanstva« (Spadaro i Cameli, 2016, 6). Za razliku od kauzističke usredotočenosti na određeni problem (casus) ili terapeutskog problem solving, takvo razlučivanje puno je više usredotočeno na životni hod kojim osoba korača ka Bogu. Upravo je u tome veličina i važnost razlučivanja kakvim ga Papa predstavlja - nije riječ o fokusiranju na jedan problem koji treba riješiti određenim aktom, nego utvrđivanju gdje i kako određena osoba, par pa i cijela zajednica mogu prepoznati znakove svega onoga što je dobro i što nije dobro za razvitak svih svojih dimenzija, osobito duhovne. Tu Papa citira i dokument koji je bez sumnje jedan od temeljnih odrednica u pastoralu braka i obitelji Familiaris consortio:

U teškim okolnostima i ranjenim obiteljima treba se uvijek spomenuti općeg načela: „Pastiri moraju znati da su, radi ljubavi prema istini, obavezni dobro razlikovati situacije“ (FC 84). Stupanj odgovornosti razlikuje se od slučaja do slučaja, te pojedini čimbenici mogu ograničiti nečiju sposobnost odlučivanja. To znači da, iako nauk treba jasno izložiti, valja izbjegavati prosudbe koje zanemaruju složenost različitih okolnosti te obratiti pozornost na način na koji osobe proživljavaju te okolnosti odnosno zbog njih trpe (AL 79).

U tom smislu tekst je ponovo jasan — naglašava važnost i nepromjenjivost nauka učiteljstva, a istovremeno želi pozvati na rast u razlučivanju, koji treba pomoći ne samo pastirima da bolje razumiju konkretnost određene situacije i na taj način prilagode svoj pristup takvoj osobi ili paru, nego posebno osobama i parovima koji su tu u pitanju da bi postepeno mogli rasti u svojem ljudskom i kršćanskom odrastanju i dostojanstvu.

Ipak, iza teksta tog dijela pobudnice, to jest činjenice da se razlučivanje ne odnosi toliko na problem koliko na život kao putovanje prema Bogu, ostaje otvoreno pitanje s obzirom na pastoralne poticaje koji, kako se čini, izviru iz tog dijela pobudnice. U pozadini se zapravo može zapaziti određeno tumačenje moralne teologije koja se, možda, ne može nazvati „moral situacije“, ali ga isto tako nije baš lako razlikovati od njega. Upravo je u tome rizik koji mnogi ističu. Riječ je o 
opasnosti (ili po nekima već učinjenoj šteti) da norme koje Crkva naučava budu razumijevane samo kao idealne postavke i (nerealni) zahtjevi, koji potom trebaju biti prilagođeni određenoj konkretnoj situaciji. Upravo u tom kontekstu Ivan Pavao II. izjavljuje da bi, ukoliko bi »nauk Crkve bio u biti samo „ideal“, koji se zatim mora prilagoditi, proporcionirati, uskladiti s onim što se naziva konkretnim čovjekovim mogućnostima, u skladu s „usklađivanjem različitih dobara koja se nude“" to bi, kako nastavlja Ivan Pavao II., bila »teška pogreška (VS 103). Zato cijeli taj govor o razlučivanju ne treba shvaćati odijeljenog od dosadašnjih izjava učiteljstva, nego upravo kako izriče i sam naslov tog poglavlja integriranog u to isto učiteljstvo.

U tom smislu važna je i nedavna Papina reakcija (Franjo, 2016) na dokument koji su izdali biskupi metropolije Buenos Aires pod nazivom „Osnovni kriteriji za primjenu poglavlja 8 'Amoris Laetitia'“ (Radio Vatikan, 2016b). Papa ponovo želi podvući važnost razumijevanja i primjenjivanja razlučivanja kako je opisano u pobudnici. Zato on naglašava hitnost formiranja svećenika za prakticiranje razlučivanja, naglasivši da je to središnje mjesto u zadatku pastoralnog praćenja obitelji u teškoćama. On također poziva na produbljenu katehezu o poticajima koji se nalaze u pobudnici, za koje kaže da će »sigurno pomoći rast, konsolidaciju i svetost obiteljskog života« (Biskupi, 2016).

U čemu je novost? Riječ je upravo o zajedničkom razlučivanju na koje su pozvani župnici i parovi, a to je upravo onaj dio pobudnice koji poziva na zajednički rast kroz razlučivanje shvaćeno kao »putovanje koje ne mora nužno voditi prema sakramentima, nego može biti orijentirano prema drugim načinima bolje integracije u život Crkve« (Biskupi, 2016, 4 [prijevod na hrv.: autori članka]). Zato cilj nije „pripuštanje“ sakramentima, kao što to nije cilj ni same pobudnice. Tekst upute prvenstveno ističe sazrijevanje i rast pomoću milosti (Biskupi, 2016, 6). Uputa upozorava i na mogućnost stvaranja konfuzije u govoru o nerazrješivosti, što smo već ranije spomenuli. Ovdje treba jasno naglasiti da su Papine pozitivne reakcije usmjerene prvenstveno na implementiranje i svojevrsnu inkulturaciju pobudnice u kulturu i prilike te partikularne crkve. U tom kontekstu očekujemo tumačenja i u okviru naše partikularne crkve, što su neki naši biskupi za svoje područje već učinili (Perić, 2016).

Naglašavanje praćenja i suradnje između pastira te osoba i parova ističe još jedan važan vid takvog razlučivanja, a to je komunitarna dimenzija Božjeg naroda u skladu s Lumen gentium 9 i 10. Iako je ovdje riječ o osobnim problemima, koji u vremenu individualizma mogu pretegnuti prema zatvaranju i ne prepoznavanju ranjenosti cijele zajednice problemom pojedinca ili para, tim više je važno naglasiti eklezijalnost u smislu susreta i otvorenosti koju ta pobudnica tako snažno ističe. O tako shvaćenoj eklezijalnosti možda nabolje svjedoče Papine riječi: »Crkva je obitelj obitelji, neprestano obogaćivana životom svih kućnih Crkava« (AL 87). Pa i onih koje su to nesavršeno ili tek djelomično.

\section{Zaključak}

Posinodalna pobudnica pape Franje Amoris laetitia bila je pod povećalom (ne samo crkvene) javnosti, i to kako tijekom njezina oblikovanja nakon sinodalnih 
zasjedanja, tako i u trenutku objavljivanja, ali i mjesecima nakon toga. Iako je i papa Franjo mogao izabrati „,igrati na sigurno“ i ne progovoriti samo biskupima ili eventualno moralnim teolozima i/ili crkvenim pravnicima, on se odlučio progovoriti cijeloj Crkvi, i to prvenstveno s pastoralno-katehetskog polazišta, pa zato možemo reći da je ta pobudnica izraz pastoralno-katehetske hrabrosti pape Franje da o temi ljubavi u obitelji prozbori iz mnogih uglova, nastojeći ne zaboraviti ni one neregularne, nesavršene i zabludjele, a što je zapravo izazvalo (pre) veliku usredotočenost na samo jedan dio pobudnice.

Tu možemo iščitati najveću prednost, koja se istovremeno pokazala i kao slabost pobudnice. Nastojeći prenijeti sinodalnu otvorenost koja je vladala tijekom Sinode i ostavljajući mogućnosti i prostora za daljnja tumačenja i rasprave - sinodalnost Crkve kroz njezine župne i biskupijske razine - Papa istovremeno potiče razlučivanje u smislu stvaranja odraslih kršćana, ne samo kod onih obitelji u teškoćama, nego na nivou cijele Crkve. Takav rizik mnoge plaši i brine, no nikako ne želimo reći da su komentari u tom smjeru neozbiljni ili površni. Dapače, oni mogu pomoći u daljnjem razlučivanju Crkve u tim osjetljivim pitanjima. Reakcije pokrajinskih crkava ne samo da su dobrodošle, nego se zapravo i očekuju u primjenjivanju općih načela na partikularne situacije u pojedinim krajevima i kulturama. Ostaje za vidjeti hoće li i naša Biskupska konferencija ili neka metropolija biti spremna dati svoje tumačenje u kontekstu naših domaćih prilika i odnosa.

$\mathrm{S}$ druge strane, prevelika fokusiranost na osmo poglavlje gubi iz vida cijeli kontekst pobudnice, njezinu namjenu i pastoralno-katehetsku poruku, koju možemo opisati kao poticaj mijenjanja mentaliteta i slike crkve kao „carinarnice“ prema „kući očevoj“ gdje sva njegova djeca mogu naći svoje mjesto.

Veći dio pobudnice zapravo je upućen obiteljima, osobito pastoralnim i katehetskim djelatnicima, te smjerodavno govori o tome kako kultivirati, rasti u ljubavi u kontekstu kulture sloboda, narcizma i egoizma, što traži vrijeme, spremnost na rizik, male korake i puno razlučivanje između stvari koje se čini kao različita dobra, a zapravo to nisu ili nisu u toj situaciji. Tu se vidi slika Crkve koju Papa promovira, kao i slika pastorala i kateheze: od zatvorenosti i krutosti prema odvažnosti i kreativnosti, ili kao što je na Međunarodnom skupu o pastoralu zvanja od 19. do 21. listopada 2016. papa Franjo rekao: potrebna je Crkva u pokretu, odvažna i kreativna Crkva koja izlazi iz krutosti i standardiziranih formula koje su često zastarjele. ${ }^{17}$

Tekst pobudnice nudi novi i produbljeni pastoralno-katehetski pogled na kršćansko katoličko umijeće ljubavi u obliku braka i obitelji u današnjem svijetu, čije se središte nalazi u razumijevanju braka kao Božjeg poziva, kojeg treba razumjeti i naviještati kao cjeloživotni proces te shvatiti kao milost za Crkvu i društvo (Siebenrock, 2016).

17 »Papa je istaknuo tri riječi: izići, vidjeti i pozvati. Potrebna je Crkva u pokretu, odvažna i kreativna Crkva koja izlazi iz krutosti i standardiziranih formula koje su često zastarjele, rekao je Sveti Otac. Vidjeti znači da treba pronaći vrijeme za susret s ljudima. Riječ „miserando“ izražava upravo zagrljaj očima i srcem, napomenuo je Papa. Treća riječ je „pozvati“. To je riječ tipična za kršćanski poziv« (HBK, 2016b). 
Obitelj je tim dokumentom potvrđena kao temeljna stanica društva i Crkve: kontinuirani subjekt pastoralnog djelovanja. Ona tu ulogu ostvaruje preko izričitog naviještanja Evanđelja i predaje svjedočanstva vjere, u solidarnosti prema siromasima, u otvorenosti različitosti osoba, u očuvanju stvorenja, preko zauzetosti za zajedničko dobro i prevladavanja nepravednih društvenih struktura. U njoj se vježbaju tjelesna i duhovna djela milosrđa. Stoga je Crkva i društvo trebaju podržavati u njezinom odgojnom nastojanju te pružiti joj sve resurse da opstane, a u naše vrijeme nanovo postane subjekt katehetskog djelovanja Crkve. Jer, kako kaže papa Franjo, svi bismo na temelju iskustva u našim obiteljima trebali moći reći: »Upoznali smo ljubav koju Bog ima za nas i prihvatili u vjeri«. Samo od tog iskustva obitelj može biti kućna Crkva i evangelizacijsko tijesto u društvu (1 Iv 4,16) (AL 290).

\section{Literatura:}

AL. Amoris laetitia. U: Papa Franjo, Amoris laetitia: Radost ljubavi: Posinodalna Apostolska pobudnica biskupima, prezbiterima i đakonima, posvećenim osobama i svim vjernicima laicima o ljubavi u obitelji. Zagreb: Kršćanska sadašnjost, 2016.

Benedikt XVI. (2012). Kateheza pape Benedikta XVI. na općoj audijenciji: Srijeda, 28. studenog 2012. URL: https://w2.vatican.va/content/benedict-xvi/hr/audiences/2012/ documents/hf_ben-xvi_aud_20121128.html (20.12.2016.)

Benedikt XVI. (2008). Govor Svetog Oca pape Benedikta XVI. Rimskoj kuriji prigodom Božićnog čestitanja Šorig. Discorso del Santo Padre Benedetto XVI alla Curia Romana in occasione della presentazione degli auguri NataliziĆ. L'osservatore Romano, 22-23.12.2008, 148(298), 6-7.

Biskupi (2016). Biskupi Pastoralne regije Buenos Aires, Directive of the bishops of the Buenos Aires Pastoral Regionto the regional clergy: September 5, 2016. URL: https://www. data.lifesitenews.com/images/pdfs/Basic_Criteria_for_the_Application_of_Chapter_VIII_of_Amoris_Laetitia_September_5_2016̄.pdf (19.10.2016.)

Catholic Herald (2016). Theologians: Amoris Laetitia needs clarification against 'heretical' interpretations. URL: http://www.catholicherald.co.uk/news/2016/07/18/theologiansamoris-laetitia-needs-clarification/ (13.10.2016)

CV. Caritas in veritate. U: Benedikt XVI., Caritas in veritate: Ljubav u istini. Enciklika o cjelovitome ljudskom razvoju u ljubavi i istini upućena biskupima, prezbiterima, đakonima, posvećenim osobama, vjernicima laicima $i$ svim ljudima dobre volje. Zagreb: Kršćanska sadašnjost, 2009.

EG. Evangelii gaudium. U: Papa Franjo, Evangelii gaudium: Radost evandelja: Apostolska pobudnica biskupima, prezbiterima i đakonima, posvećenim osobama i svim vjernicima laicima o naviještanju evanđelja u današnjem svijetu. Zagreb: Kršćanska sadašnjost, 2013.

Fares, Diego Javier (2016). Educare i figli secondo «Amoris Laetitia»: La pedagogia di papa Francesco. La Civiltà Cattolica, 164, 3982, 356-368.

Franjo (2013). Viaggio apostolico a Rio de Janeiro in occasione della XXVIII giornata mondiale della gioventù: Conferenza stampa del Santo Padre Francesco durante il volo di ritorno: Volo Papale: Domenica, 28 luglio 2013. URL: http://w2.vatican.va/ content/francesco/it/speeches/2013/july/documents/papa-francesco_20130728_gmg_ conferenza-stampa.html (22. 10. 2016.)

Franjo (2015a). O odgoju: Izazovi za kršćanske odgojitelje. Split: Verbum.

Franjo (2015b). Papina opća audijencija 04.03.2015. URL: http://w2.vatican.va/content/francesco/en/audiences/2015/documents/papa-francesco_20150304_udienza-generale.html 
Franjo (2015c). Papina opća audijencija 20.05.2015. URL: http://w2.vatican.va/content/ francesco/en/audiences/2015/documents/papa-francesco_20150520_udienza-generale.html

Franjo (2016). Text of Letter of Pope Francis to Mons. Sergío Alfredo Fenoy, Delegate of the Buenos Aires Pastoral Region: September 5, 2016. URL: https://www.lifesitenews. com/images/pdfs/Letter_of_pope_to_Pastoral_Region_of_Buenos_Aires_September_5_2016.pdf (19.10.2016.)

Fuček, Ivan (2004). Grijeh: Obraćenje: Moralno-duhovni život. Split: Verbum.

Garmaz, Jadranka; Gašpar, Angelina (2016). Interrelatedness of Religious Education and Family Analysed Through Key Terminology Extracted from Theological Texts. Bogoslovni vestnik, 76, 2, 417-433.

Garmaz, Jadranka; Kraml, Martina (2010). Živjeti od euharistije: Elementi euharistijske kateheze. Zagreb: Glas Koncila.

HBK (2002). Hrvatska biskupska konferencija, Na svetost pozvani: Pastoralne smjernice na početku trećega tisućljeća. Zagreb: Glas Koncila.

HBK (2016a). Hrvatska biskupska konferencija, »Da vaša radost bude potpuna« (Iv 15,11): Kateheza i rast u vjeri u današnjim okolnostima: Radni dokument. URL: http://www.zg-nadbiskupija.hr/UserDocsImages/stories/SLIKE/2016/11/1/Da\%20 va\%C5\%A1a\%20radost $\% 20$ bude $\% 20$ potpuna $\% 20-\% 20$ Kateheza $\% 20$ i $\% 20$ rast $\% 20 u \% 20 v j e r i \% 20 . p d f(20.12 .2016$.)

HBK (2016b). Hrvatska biskupska konferencija, Međunarodni skup o pastoralu zvanja. URL: http://www.hbk.hr/?type =vijest \&ID=618 (20.12.2016.)

Ivan Pavao II. (1999). Pismo pape Ivana Pavla II. starijim osobama. Zagreb: Kršćanska sadašnjost.

Kasper, Walter (2015). Milosrđe: Temeljni pojam evanđelja — ključ kršćanskog života. Zagreb: Kršćanska sadašnjost.

Koprek, Ivan (2005). Priđi da možeš čuti: Etika u sjeni globalizacije i postmoderne. Zagreb: Filozofsko-teološki institut Družbe Isusove.

Kovačević, Vinko (2014). Odgoj za osobne i društvene dimenzije kršćanskih vrednota. Školski vjesnik, 63, 1-2, 91-106.

Martin, James (2016). Understanding discernment is key to understanding "Amoris Laetitia”. URL: http://www.americamagazine.org/issue/discernment-key-amoris-laetitia (19.10.2016.)

Matulić, Tonči (2016). »Bog u pitanju« kao izazov za teologiju. U: Marijan Steiner i Ivan Šestak (ur.), Aktualne moralne teme (str.71-101). Zagreb: Filozofsko-teološki institut Družbe Isusove.

MD. Mulieris dignitatem. U: Ivan Pavao II., Mulieris dignitatem: Apostolsko pismo o dostojanstvu i pozivu žene prigodom Marijanske godine. Zagreb: Kršćanska sadašnjost, 1989.

Murdoch, Jessica M. (2016). Creeping infallibility. URL: https://www.firstthings.com/webexclusives/2016/09/creeping-infallibility (13.10.2016)

MV. Misericordiae Vultus. U: Franjo, Misericordiae Vultus: Lice milosrda: Bula najave izvanrednoga jubileja milosrđa. Zagreb: Kršćanska sadašnjost.

Perić, Ratko (2016). Biskup Perić uputio okružnicu "Podsjetnik ispovjednicima". URL: http://www.ktabkbih.net/info.asp?id=66222 (10.11.2016.)

Pismokatoličkih profesora filozofijeiteologije(2016).URL:http://2n613ar7ekr056c3upq2s15c. wpengine.netdna-cdn.com/wp-content/uploads/2016/07/cardinal-letter2.pdf $(13.10 .2016)$ 
Radio Vatikan (2016a). Schönborn:Amoris Laetitia ist,,Aktdes kirchlichen Lehramts“.URL: http://de.radiovaticana.va/news/2016/07/07/sch\%C3\%B6nborn_amoris_laetita_ist_\%E2\%80\%9Eakt_\%20des_kirchlichen_lehramts\%E2\%80\%9C/1242651 (20.12.2016.)

Radio Vatikan (2016b). Pope endorses Argentine bishops' document on Amoris Laetitia. URL: http://en.radiovaticana.va/news/2016/09/12/pope_endorses_argentine_bishops_ document_on_amoris_laetitia/1257635 (19.10.2016.)

Siebenrock, Roman (2016). Tagung zu "Amoris laetitia". URL: http://www.bz-bx.net/ home_deu/ordinariat/00035603_Tagung_zu_Amoris_laetitia.html (20.12.2016.)

Sievernich, Michael (2016). Von der Kunst persönlicher und pastoraler »Unterscheidung« im Kontext der Familie. Theologische Quartalschrift, 196, 4, 355-370.

Spadaro, Antonio; Cameli, Louis J. (2016). La sfida del discernimento in «Amoris laetitia». La Civiltà Cattolica, 167, 3985, 3-16.

Šimundža, Drago (2000). Civilizacija ljubavi. Split: Laus.

VS. Veritatis splendor. U: Ivan Pavao II., Veritatis splendor: Sjaj istine: Enciklika o nekim temeljnim pitanjima moralnog naučavanja Crkve. Zagreb: Kršćanska sadašnjost.

The Pastoral and Educational-Catechetical Highlights in Chapters Seven and Eight of the Post-Synodal Apostolic Exhortation Amoris Laetitia

Jadranka Garmaz*, Antun Volenik**

\section{Summary}

The article elaborates on the pastoral, educational and catechetical highlights in Chapters Seven and Eight of the Apostolic Exhortation Amoris Laetitia, whereby the authors, Jadranka Garmaz and Antun Volenik, explain the said chapters entitled respectively, Toward a Better Education of Children and Accompanying, Discerning and Integrating Weakness. These two chapters condense the catechetical and pastoral specificity of the Exhortation and pose a major challenge, for they discuss the issues of raising children, their moral and religious education, and they reaffirm some forgotten pastoral guidelines. Namely, until now not a single official document of the universal Church has devoted so many paragraphs to the concrete problem of families providing children with a religious upbringing as is evident in Chapter Seven. Chapter Eight, in the context of the Extraordinary Jubilee of Mercy, pertains to the change in mentality which the Exhortation proposes in terms of depicting the Church as the Father's House rather than a customs office.

Key words: Amoris Laetitia-The Joy of Love, family upbringing, moral upbringing, religious education, discernment, Extraordinary Jubilee of Mercy

* Associate Professor Jadranka Garmaz, Ph.D., Catholic Faculty of Theology, University of Split. Address: Zrinsko-frankopanska 19, 21000 Split, Croatia. E-mail: j.garmaz @kbf-st.hr

** Antun Volenik, Ph.D., Faculty of Philosophy and Religious Sciences, University of Zagreb. Address: Jordanovac 110, 10000 Zagreb, Croatia. E-mail: voleniksj@gmail.com 